\title{
Analisis Regresi Logistik Ordinal Faktor-Faktor Yang Mempengaruhi Ipk Mahasiswa
}

\author{
Dwi Utami Setyawati ${ }^{1}$, Baiq Dewi Korida ${ }^{2}$, Baiq Rika Ayu Febrilia ${ }^{2}$ \\ ${ }^{1,2,3}$ Program Studi Pendidikan Matematika, Universitas Pendidikan Mandalika, Mataram \\ ${ }^{1}$ utamiwi.25@gmail.com, ${ }^{2}$ baiqdewikorida12@gmail.com, ${ }^{3}$ rikafebrilia@ikipmataram.ac.id \\ DOI 10.30812/varian.v3i2.615
}

\section{INFO ARTIKEL}

\section{Riwayat Artikel:}

Diterima: 13-01-2020

Disetujui: 09-03-2020

\section{Kata Kunci:}

Regresi Logistik Ordinal Faktor-faktor IPK

\section{ABSTRAK}

Abstrak: Setiap mahasiswa memiliki perbedaan dalam mengikuti proses pembelajaran yang akan mempengaruhi prestasi belajarnya atau yang biasa dikenal dengan Indeks Prestasi Kumulatif (IPK) mahasiswa. Untuk meningkatkan IPK mahasiswa dan kualitas proses pembelajaran di kelas, maka penting untuk diketahui faktor-faktor yang mempengaruhinya. Faktor-faktor yang akan diuji tersebut diantaranya jurusan SMA dan asal daerah mahasiswa. Analisis faktor-faktor tersebut dapat menggunakan analisis regresi logistik ordinal yang mana setiap variabelnya dikategorikan menggunakan skala tertentu. Penelitian ini menggunakan data mahasiswa Program Studi Pendidikan Matematika angkatan 2010-2013 yang lulus pada tahun 2017 dan 2018. Hasil penelitian menunjukkan bahwa kedua faktor tersebut berpengaruh secara signifikan terhadap IPK mahasiswa. Penelitian ini diharapkan dapat menjadi salah satu sumber referensi dalam meningkatkan kualitas mahasiswa di program studi.

Abstract: Every student has a difference in following the learning process that will affect their learning achievement or commonly known as the Grade Point Average (GPA). To improve student GPA and the quality of the learning process in class, it is important to know the factors that influence it. The factors to be tested include high school majors and student area of origin. Analysis of these factors can use ordinal logistic regression analysis, where each variable is categorized using a certain scale. This study used the data of Mathematics Education Department students from 2010-2013 who graduated in 2017 and 2018. The results showed that both of these factors significantly influenced student GPA. This research is expected to be one of the sources of reference in improving the quality of students in the department.

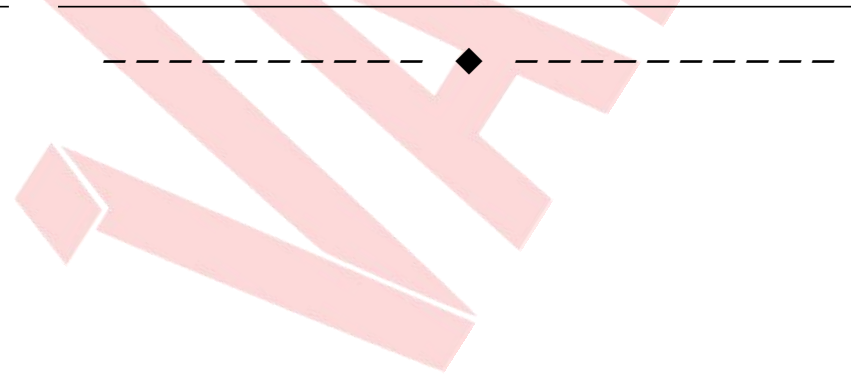




\section{A. LATAR BELAKANG}

Pada perguruan tinggi, mahasiswa dituntut untuk menjadi seseorang yang aktif saat proses belajar mengajar berlangsung. Hal ini akan menunjang keberhasilan akademik mahasiswa melalui penyelesaian tugas-tugas secara efektif (Alfiana, 2013). Adanya keberhasilan akademik ditandai dengan perolehan prestasi akademik yang akan dicapai. Perolehan prestasi akan dikontrol oleh setiap perguruan tinggi guna menghasilkan lulusan mahasiswa yang memiliki mutu yang berkualitas. Kualitas prestasi dapat diukur melalui indeks prestasi kumulatif (IPK) yang diperoleh oleh mahasiswa dalam bidang akademik.

Indeks prestasi kumulatif (IPK) dapat dipengaruhi oleh beberapa faktor yaitu jurusan di SMA, asal sekolah baik dari SMA, MA dan SMK, asal daerah mahasiswa, serta jenis kelamin. Hal ini sejalan dengan penelitian terdahulu yaitu menyatakan bahwa IPK sangat dipengaruhi oleh asal sekolah, yang mana mahasiswa berasal dari SMA dan SMK memiliki IPK yang lebih tinggi dibandingkan dengan MA (Qudratullah, 2014), mahasiswa dengan jurusan IPA memilih program studi apapun akan mendapatkan IPK memuaskan sebesar 66\% berbeda dengan jurusan non-IPA akan mendapatkan IPK kurang memuaskan 49\% (Buaton, Sihombing, Aritonang, \& Wijaya, 2017), dengan kata lain bahwa jurusan mahasiswa di SMA sangat signifikan dalam mempengaruhi kategori IPK pada perguruan tinggi (Linuhung \& Suryadinata, 2019), asal daerah dari luar Surabaya memiliki IPK > 3,50 lebih banyak dibandingkan dengan IPK di antara 2,76 hingga 3,50 (Imaslihkah, Ratna, \& Ratnasari, 2013a), serta adanya perbedaan prestasi akademik antara laki-laki dan perempuan (Linuhung \& Suryadinata, 2019). Pendapat lain yang mengatakan bahwa IPK yang dimiliki perempuan lebih tinggi dibandingkan dengan laki-laki karena perempuan cenderung mampu mengatasi emosional dalam belajar, sedangkan laki-laki sebaliknya (Oktarisa \& Yusra, 2015). Adapun pendapat lain yang menyatakan bahwa terdapat pengaruh asal sekolah dan tempat tinggal terhadap prestasi belajar atau dikenal dengan IPK pada perguruan tinggi, di mana asal sekolah memberi nilai signifikan 0,008 $<0,05$, sedangkan tempat tinggal mempunyai nilai sebesar 0,040<0,05 (Indriyani, 2014). Dari faktor-faktor yang telah dipaparkan, maka perlu dilakukan pengukuran seberapa pengaruhnya terhadap IPK.

Pengaruh faktor-faktor tersebut dapat diketahui dengan adanya analisis statistik. Analisis yang digunakan guna mengetahui pengaruh antar suatu peubah yaitu analisis regresi (Fatonah, Sanapiah, \& Febrilia, 2017). Regresi yaitu alat statistik yang digunakan untuk melihat hubungan sebab akibat antara dua peubah lainnya (RIYANTINI, SUSILAWATI, \& SARI, 2014). Analisis regresi terdapat dua jenis peubah yaitu peubah predikat $(\mathrm{X})$ yang memengaruhi dan peubah respon $(\mathrm{Y})$ yang dipengaruhi. Adapun kegunaan dari regresi logistik yaitu untuk melihat pengaruh X terhadap $\mathrm{Y}$, sehingga dalam menganalisis $\mathrm{Y}$ data kategori pada analisis regresi yang tepat dengan menggunakan analisis regresi logistik. Analisis regresi logistik yaitu metode statistika untuk mendeskripsikan hubungan peubah respon yang terdiri dari dua kategori atau lebih dengan peubah predikat yang berskala interval, hal ini bertujuan untuk mengetahui pengaruh antara variabel yang satu dengan yang lainnya (Tampil, Komaliq, \& Langi, 2017)

Model regresi yaitu model yang berfungsi untuk menampilkan hubungan suatu variabel respon dengan variabel bebas. Suatu model regresi, jika variabel respon yaitu dikotomis, sehingga saat menganalisis haruslah menggunakan model regresi logistik, yang mana parameter estimasi menggunakan fungsi sebagai penghubungnya (Yulian \& Pawitan, 2017). Adapun model regresi yang paling sederhana yaitu regresi linear yang memilki persamaan seperti berikut(Tampil et al., 2017)

$Y=\beta_{0}+\beta_{1} X+\varepsilon$

Keterangan:

$Y \quad=$ variabel terikat

$\beta_{0}=$ konstanta

$\beta_{1}=$ koefisien regresi

$X=$ variabel bebas 
$\varepsilon \quad=$ galat acak

Model regresi logistik ordinal disebut model logit kumulatif, yang mana model logistik ini bertujuan untuk respon ordinal dengan peubah respon berupa data bertingkat dan diawali dengan angka $1,2,3, \ldots, m$, dimana $m$ yaitu banyaknya kategori respon (Tampil et al., 2017). Model umum dari regresi logistik ordinal adalah sebagai berikut.

$$
\begin{aligned}
\operatorname{logit}(P[Y \leq m \mid x]) & =\log \left(\frac{P[Y \leq m \mid x]}{P[Y>m \mid x]}\right) \\
& =\log \left(\frac{P[Y \leq m \mid x]}{1-P[Y \leq m \mid x]}\right) \\
& =\boldsymbol{\gamma}_{0 m}+\sum_{t=1}^{p} \boldsymbol{\gamma}_{t} x_{i t}
\end{aligned}
$$

dengan $m=1,2, \ldots, M-1$ dan $\boldsymbol{\gamma}$ adalah vektor dari koefisien regresinya. untuk menduga parameter model dari regresi logistik ordinal. Untuk menduga hal tersebut dapat dilakukan apabila diasumsikan untuk $\mathrm{n}$ penelitian, $y_{i}$ variabel tak bebas dimana $i=1,2, \cdots, n$ adalah suatu variabel acak (Fauzy, 2014).

Model regresi logistik ordinal yang telah diperoleh perlulah dilakukan suatu uji parsial dan uji serentak, yang mana uji ini bertujuan untuk menguji keefesien $\beta$ secara parsial yang menggunakan uji statistik.

Hipotesis :

$$
H_{0}: \beta_{k}=0 \quad H_{1}: B_{k} \neq 0 ; k=1,2, \ldots, p
$$

Uji statistik yang digunakan yaitu statistik uji Wald.

$$
W=\frac{\beta_{k}}{S E\left(\beta_{k}\right)}
$$

dimana, daerah penolakan $H_{0}$ adalah $|W|>Z_{\alpha / 2}$ atau $W^{2}>X^{2}(\alpha, v)$, dengan nilai p-value $<\alpha$. Untuk uji serentak ini bertujuan untuk memeriksakan keefesien $\beta$ terhadap variabel respon secara bersama dengan uji statistik.

Hipotesis :

$H_{0}: B_{1}=B_{2}=\ldots=B_{k}=0$

$H_{1}$ : yang mana memiliki minimal satu $B_{k} \neq 0 ; k=1,2, \ldots, p$

Uji statistik yang digunakan yaitu uji $\mathrm{G}$

$G^{2}=-2 \ln \left[\frac{\left(\frac{n_{0}}{n}\right)^{n_{0}}\left(\frac{n_{1}}{n}\right)^{n_{1}}\left(\frac{n_{2}}{n}\right)^{n_{2}}}{\prod_{i=1}^{n}\left[\pi 0\left(x i^{y 0 i}\right) \pi 1\left(x i^{y 1 i}\right) \pi 2\left(x i^{y 2 i}\right)\right]}\right]$

yang mana,

$n 0=\sum_{i=1}^{n} y 0 i, n 1=\sum_{i=1}^{n} y 1 i, n 2=\sum_{i=1}^{n} y 2 i, n=n 0+n 1+n 2$

Daerah penolakan $H_{0}$ yaitu jika $G^{2}>X^{2}(\alpha, v)$, dengan nilai p-value $<\alpha$, yang mana uji G mengikuti Chisquare dengan derajat bebas $p(I m a s l i h k a h$, Ratna, \& Ratnasari, 2013b).

Berdasarkan pemaparan di atas, maka fokus dari penelitian ini adalah untuk menganalisis regresi logistik ordinal dari faktor-faktor yang mempengaruhi IPK mahasiswa Program Studi Pendidikan Matematika Undikma Mataram (dalam hal ini faktor yang dimaksud adalah jurusan SMA mahasiswa dan asal daerah). Penelitian ini diharapkan dapat menjadi salah satu referensi kebijakan prodi khususnya dalam program penyetaraan kemampuan dasar matematika setiap calon mahasiswa sehingga nilai IPK mahasiswa tidak terlalu berbeda secara signifikan meskipun berbeda latar belakang jurusan SMA dan asal daerah. 


\section{B. METODE PENELITIAN}

1. Sumber Data

Data yang digunakan dalam penelitian ini adalah data sekunder, yang diperoleh melalui permohonan data dari Biro Administrasi Akademik dan Kemahasiswaan (BAAK) dan Tata Usaha (TU) Fakultas Pendidikan Matematika dan Ilmu Pengetahuan Alam (FPMIPA) Universitas Pendidikan Mandalika (Undikma) Mataram.

\section{Subjek Penelitian}

Adapun subjek penelitian ini yaitu mahasiswa Prodi Pendidikan matematika Universitas Pendidikan Mandalika Mataram angkatan 2010-2013 sebanyak 108 orang mahasiswa. Teknik penelitian yang digunakan yaitu purposive, karena sampel yang diambil berdasarkan tujuan penelitian yang diinginkan peneliti.

3. Variabel Penelitian

Beberapa variabel yang digunakan dalam penelitian ini adalah IPK, asal daerah dan jurusan pada waktu SMA mahasiswa. Berikut pemaparan mengenai variabel yang digunakan dalam penelitian beserta kategori dari setiap variabel.

Variabel respon atau variabel $Y$ dalam penelitian ini adalah IPK dengan skala ordinal yang ditentukan mengikuti kriteria berikut.

$1=I P K>3,50\left(Y_{1}\right)$

$2=3,00 \leq I P K \leq 3.50\left(Y_{2}\right)$

$3=I P K<3,00\left(Y_{3}\right)$

Berkaitan dengan variabel prediktor, variabel yang digunakan sebanyak dua variabel yaitu variabel jurusan SMA $\left(X_{1}\right)$ dan asal daerah $\left(X_{2}\right)$. Variabel jurusan SMA dikategorikan menjadi dua kategori ordinal, yaitu jurusan IPA, IPS dan yang lainnya.

$1=$ Jurusan IPA $\left(X_{1.1}\right)$

$2=$ Jurusan IPS $\left(X_{1.2}\right)$

3 = Jurusan lainnya $\left(X_{1.3}\right)$

Sedangkan variabel asal daerah dikategorikan menjadi dua yaitu Mataram dan luar Mataram dengan pembagian berikut.

$1=$ Mataram $\left(X_{2.1}\right)$

$2=$ Luar Mataram $\left(X_{2.2}\right)$

4. Prosedur Penelitian

Penelitian ini mengikuti langka-langkah berikut.

1. Mengumpulkan data.

2. Mengategorikan masing-masing variabel berdasarkan kategori skala ordinal yang telah ditentukan.

3. Menganalisis data menggunakan analisis regresi logistik ordinal dengan berbantuan software.

4. Membuat tabel untuk menentukan karakteristik mahasiswa.

5. Menduga parameter regresi logistik ordinal.

6. Menguji signifikansi parameter secara menyeluruh dan parsial.

Menguji model yang diperoleh apakah mengikuti regresi logistik ordinal atau tidak.

\section{HASIL DAN PEMBAHASAN}

Analisis karakteristik Indeks Prestasi Kumulatif (IPK) mahasiswa Prodi Pendidikan Matematika angkatan 2010-2013 IKIP Mataram menunjukkan bahwa 8.3\% dari mahasiswa tersebut memiliki IPK lebih dari 3,50, sebanyak 86.1\% mahasiswa memiliki IPK kurang dari atau sama dengan 3,50 dan lebih dari atau 
sama dengan 3, sedangkan 5,6\% di antaranya memiliki IPK kurang dari 3,00. Ringkasan datanya dapat dilihat dalam Tabel 1.

Tabel 1. Persentase IPK mahasiswa Prodi Pendidikan Matematika angkatan 2010-2013

\begin{tabular}{cc}
\hline IPK & Persentase \\
\hline$>3,50$ & $8,3 \%$ \\
$3,00 \leq I P K \leq 3.50$ & $86,1 \%$ \\
$I P K<3,00$ & $5,6 \%$ \\
\hline
\end{tabular}

Hal ini dimungkinkan terjadi karena beberapa faktor, baik itu internal atau eksternal. Faktor internalnya yaitu siswa susah dalam menyerap materi kuliah yang diberikan oleh dosen ataupun kurang disiplin dari siswa itu sendiri dalam proses pembelajaran di kelas(Febrilia, Rahayu, \& Korida, 2019) sedangkan faktor eksternalnya yaitu adanya kekurangan biaya untuk menunjang fasilitas dalam belajar, asal daerah ataupun jurusan pada SMA nya.

Selanjutnya disajikan tabel karakteristik jurusan SMA terhadap masing-masing kategori IPK mahasiswa.

Tabel 2. Karakteristik Jurusan SMA terhadap IPK

\begin{tabular}{ccccc}
\hline \multirow{2}{*}{ Jurusan SMA } & \multicolumn{3}{c}{ IPK Mahasiswa } & \multirow{2}{*}{ Total } \\
\cline { 2 - 4 } & $I P K>3,50$ & $3,00 \leq I P K \leq 3,50$ & $\mathbb{I P K}<3,00$ & \\
\hline IPA & $7(12,5 \%)$ & $46(82,14 \%)$ & $3(5,36 \%)$ & $56(100 \%)$ \\
IPS & $2(4,26 \%)$ & $45(95,74 \%)$ & $0(0 \%)$ & $47(100 \%)$ \\
Lainnya & $0(0 \%)$ & $2(40 \%)$ & $3(60 \%)$ & $5(100 \%)$ \\
\hline
\end{tabular}

Berdasarkan Tabel 2, diperoleh informasi bahwa mahasiswa angkatan tahun 2010-2013 baik yang berasal dari SMA jurusan IPA maupun IPS sebagian besar memiliki IPK di antara 3,00 dan 3,50 dengan persentase secara berturut-turut 82,14\% (46 dari 56 mahasiswa) dan 95,74\% (45 dari 47 mahasiswa), sedangkan mahasiswa dengan jurusan SMA selain IPA dan IPS lebih banyak memperoleh IPK kurang dari 3,00 (3 dari 5 mahasiswa atau sebesar 60\%). Persentase mahasiswa dengan IPK yang bernilai lebih dari 3,50 pada jurusan IPA hanya 12,5\% (7 dari 56 mahasiswa), sedangkan pada jurusan IPS hanyalah 4,26\% (2 dari 47 mahasiswa). Tidak ada mahasiswa selain jurusan IPA dan IPS yang memperoleh IPK lebih dari 3,50. Nilai persentase sisanya adalah mahasiswa Hal ini dapat disimpulkan bahwa mahasiswa yang berasal dari SMA jurusan IPA banyak mendominasi dengan IPK lebih dari 3,00 bahkan proporsinya cukup tinggi dibandingkan jurusan lainnya pada IPK lebih dari 3,50. Hal ini dimungkinkan terjadi karena mahasiswa dari jurusan IPA mendapatkan materi matematika yang cukup mendalam jika dibandingkan jurusan lainnya sehingga mereka lebih siap dalam menerima setiap materi yang diberikan pada perkuliahan di Prodi Pendidikan Matematika.

Tabel 3 berikut adalah tabel mengenai karakteristik IPK mahasiswa jika ditinjau dari asal daerahnya.

Tabel 3. Karakteristik Asal Daerah terhadap IPK

\begin{tabular}{ccccc}
\hline \multirow{2}{*}{ Asal Daerah } & \multicolumn{3}{c}{ IPK Mahasiswa } & \multirow{2}{*}{ Total } \\
\hline Mataram & $2(50 \%)$ & $3,00 \leq I P K \leq 3,50$ & $I P K<3,00$ & $4(100 \%)$ \\
Luar Mataram & $7(6,3 \%)$ & $2(50 \%)$ & 0 & $104(100 \%)$ \\
\hline
\end{tabular}

Berdasarkan Tabel 3, diperoleh data yang menunjukkan bahwa sebagian besar mahasiswa angkatan 20102013 di Prodi Pendidikan Matematika berasal dari luar Kota Mataram, sekitar 96\% atau 104 dari 108 mahasiswa. Mahasiswa yang berasal dari luar kota lebih banyak mencapai IPK di antara 3,00 dan 3,50 (87.5\% atau 91 dari 104 mahasiswa). Tingkat persentase sebesar 6,73\% (atau 7 dari 104 mahasiswa) memiliki IPK lebih dari 3,50 dan sisanya adalah dengan IPK kurang dari 3,00. Untuk mahasiswa yang berasal dari Kota Mataram, persentase mahasiswa yang memperoleh IPK lebih dari 3,50 dan diantara 3,00 dan 3,50 
seimbang dengan masing-masing terdiri atas 2 orang mahasiswa. Tidak ada mahasiswa yang berasal dari Kota Mataram yang memperoleh IPK kurang dari 3,00.

Setelah menganalisis karakteristik IPK, langkah selanjutnya adalah menduga parameter model regresi logistik ordinal dengan menggunakan bantuan software SPSS. Ringkasan hasil estimasi diberikan pada Tabel 4.

Tabel 4. Estimasi Parameter Model dari Regresi Ordinal

\begin{tabular}{cccccc}
\hline Variabel & Kategori & Koefisien $(\beta)$ & Standar Eror & Exp $(\beta)$ & P-value \\
\hline \multirow{2}{*}{ IPK $(Y)$} & Konstanta 1 & $-6,484$ & 1,147 & & 0,000 \\
& Konstanta 2 & $-0,408$ & 0,913 & & 0,655 \\
\multirow{3}{*}{ Jurusan SMA $\left(X_{1}\right)$} & IPA $\left(X_{1.1}\right)$ & $-4,056$ & 1,137 & 0,017 & 0,000 \\
& IPS $\left(X_{1.2}\right)$ & $-3,712$ & 1,127 & 0,024 & 0,001 \\
\multirow{2}{*}{ Asal Daerah $\left(X_{2}\right)$} & Lainnya $\left(X_{1.3}\right)$ & & & & \\
& Mataram $\left(X_{2.1}\right)$ & $-2,605$ & 1,078 & 0,074 & 0,016 \\
\hline
\end{tabular}

Tabel 4 menunjukkan bahwa IPK (Y) merupakan dua nilai konstanta pada setiap logit, yang mana diperoleh karena model terdiri atas tiga kategori. Dua konstanta ini mengakibatkan adanya dua model logit. Tabel 4 juga menginformasikan nilai koefisien, standar eror koefisien, nilai odds ratio ( ( ) ) dan P-value masing-masing kategori dari variabel. Nilai odds ratio mahasiswa dengan SMA dari jurusan IPS adalah 0,024, yang artinya mahasiswa dengan jurusan IPS saat SMA memiliki peluang IPK 0,024 lebih kecil dibandingkan kategori yang lain. Untuk variabel asal daerah, nilai odds ratio mahasiswa yang berasal dari Kota Mataram sebesar 0,074. Hal ini menunjukkan bahwa peluang IPK mahasiswa yang berasal dari Kota Mataram 0,074 lebih kecil dibandingkan yang lain.

Tabel 5 berikut memaparkan hasil uji kesesuaian model yang diperoleh. Maksudnya adalah apakah model tersebut cocok atau tidak dengan model regresi logistik ordinal. Uji kecocokan modal ini menggunakan hipotesis berikut.

$\mathrm{H}_{0}$ : Model sesuai

$\mathrm{H}_{1}$ : Model tidak sesuai

Tabel 5. Uji Kesesuaian Model

\begin{tabular}{ccccc}
\hline & Chi-Square & df & P-value & Keputusan \\
\hline Deviance & 7,057 & 5 & 0,216 & $\mathrm{H}_{0}$ diterima \\
\hline
\end{tabular}

Tabel 5 menyatakan bahwa nilai $P=0,216>0,05$, sehingga keputusan dari hasil uji kesesuaian model ini adalah menerima $\mathrm{H}_{0}$. Dengan kata lain dapat disimpulkan bahwa model regresi ordinal yang telah diperoleh telah sesuai.

Tabel 6. Uji Keseluruhan Parameter Model Menggunakan Likelihood Ratio

\begin{tabular}{cccccc}
\hline Model & $G 2$ & Chi-Square & df & P-value & Keputusan \\
\hline Final & 20,400 & 18,165 & 3 & 0,000 & $\mathrm{H}_{0}$ ditolak \\
\hline
\end{tabular}

Pengujian pada Tabel 6 didasarkan pada hipotesis berikut.

$\mathrm{H}_{0}: \beta_{1}=\beta_{2}=0$

$\mathrm{H}_{1}$ : Minimal ada satu $\beta_{i} \neq 0, i=1,2$

Berdasarkan Tabel 6 diperoleh bahwa nilai $G 2>\chi_{(0,05 ; 3)}=7,815$ artinya H0 ditolak dengan kata lain minimal ada satu parameter yang signifikan sehingga diperlukan pengujian secara parsial. Hasil ini juga sesuai dengan $P$-value $=0,000<0,05$.

Uji parsial mengacu pada nilai P-value setiap parameter yang disajikan oleh Tabel 4. Hal ini dimaksudkan untuk menentukan variabel prediktor yang cukup signifikan dengan memperhatikan hipotesis berikut. 
$\mathrm{H}_{0}: \beta_{j}=0$

$\mathrm{H}_{1}: \beta_{j} \neq 0, j=1,2$

Berdasarkan nilai $\mathrm{P}$-value yang tertera, nilai variabel prediktor yang signifikan adalah yang memiliki $P$ value $<0,05$, yaitu variabel $X_{1.1}, X_{1.2}$ dan $X_{2.1}$. Oleh karena itu, model logit yang diterima adalah

$$
\begin{aligned}
& \operatorname{Logit}\left(y_{1}\right)=\log \left(\frac{y_{1}}{1-y_{1}}\right)=-6,484+\left(-4,056 X_{1,1}\right)+\left(-3,712 X_{1,2}\right)+\left(-2.605 X_{2,1}\right) \\
& \text { Logit }\left(y_{2}\right)=\log \left(\frac{y_{2}}{1-y_{2}}\right)=-0,408+\left(-4,056 X_{1,1}\right)+\left(-3,712 X_{1,2}\right)+\left(-2.605 X_{2,1}\right)
\end{aligned}
$$

\section{SIMPULAN DAN SARAN}

\section{Simpulan}

Berdasarkan hasil penelitian yang telah dipaparkan di atas dapat diambil kesimpulan bahwa hasil analisis secara menyeluruh dan parsial menyatakan bahwa faktor-faktor yang mempengaruhi dari indeks prestasi kumulatif adalah jurusan SMA dan asal daerah mahasiswa. Karakteristik mahasiswa dari Program Studi Pendidikan Matematika angkatan 2010-2013 didominasi oleh mahasiswa yang memperoleh IPK diantara 3,00 dan 3,50 dengan didominasi oleh mahasiswa yang berlatar belakang SMA jurusan IPS dan berasal dari luar kota Mataram.

\section{Saran}

Saran untuk penelitian berikutnya adalah perlu dipertimbangkan faktor-faktor lainnya yang mungkin juga turut memberikan pengaruh terhadap peningkatan IPK seseorang. Faktor-faktor tersebut dapat diuji secara bersama-sama atau terpisah dalam mempelajari lebih jauh bagaimana pengaruhnya.

\section{REFERENSI}

A. D. Alfiana. (2013). "Regulasi Diri Mahasiswa Ditinjau dari Keikutsertaan dalam Organisasi Kemahasiswaan”. J. Ilm. Psikol. Terap., vol. 1, no. 2, pp. 245-259, doi: 10.26877/empati.v6il.4115.

M. F. Qudratullah. (2014). "Pengaruh Jalur Penerimaan Mahasiswa dan Asal Sekolah Terhadap Prestasi Mahasiswa di Fakultas Sains dan Teknologi UIN Sunan Kalijaga”. J. Fourier, vol. 3, no. 1, pp. 9-15, doi: 10.14421/fourier.2014.31.9-15.

R. Buaton, A. Sihombing, F. D. Aritonang, and C. R. Wijaya. (2017). "Data Mining untuk Menentukan Korelasi ( Confidence dan Support ) Jurusan Siswa pada Tingkat Sekolah Menengah terhadap Indeks Prestasi Kumulatif ( Ipk ) Di Perguruan Tinggi sebagai Solusi Tepat Pemilihan Program Studi Di Perguruan Tinggi,” J. Sist. Inf. Kaputama, vol. 1, no. 2, pp. $1-13$.

N. Linuhung and N. Suryadinata. (2019). "Analisis Keberhasilan Akademik Mahasiswa Program Studi Pendidikan Matematika Universitas Muhammadiyah Metro”. J. Progr. Stud. Pendidik. Mat., vol. 8, no. 1, pp. 73-82.

S. Imaslihkah, M. Ratna, and V. Ratnasari. (2013). "Analisis Regresi Logistik Ordinal terhadap Faktor-faktor yang mempengaruhi Predikat Kelulusan Mahasiswa S1 di ITS Surabaya”. J. Sains dan Seni Pomits ISSN 2337-3520 (2301928X Print), vol. 2, no. 2, pp. 177-182.

F. Oktarisa and Z. Yusra. (2015). "Perbedaan Prestasi Akademik Ditinjau dari Coping Stress dan Jenis Kelamin pada PERS Mahasiswa". J. RAP UNP, vol. 6, no. 2, pp. 136-145.

R. Indriyani. (2014). "Pengaruh Asal Sekolah dan Tempat Tinggal terhadap Prestasi Belajar Mahasiswa Prodi DIII Kebidanan Universitas Wiraja Sumenep". J. Kesehat. "Wiraraja Med., vol. 4, no. 1, pp. 34-39, doi: 10.1017/CBO9781107415324.004.

L. Fatonah, S. Sanapiah, and B. R. A. Febrilia. (2017)."Regresi Logistik Ordinal (Studi Kasus Faktor yang Mempengaruhi Tingkat Stres Mahasiswa dalam Menyelesaikan Skripsi)," Media Pendidik. Mat., vol. 5, no. 2, pp. 146-159, doi: 10.33394/mpm.v5i2.1501.

D. L. RiyantiniI, M. Susilawati, and K. Sari. (2014). "Penerapan Regresi Akar Laten dalam Menangani Multikolinearitas pada Model Regresi Linier Berganda”. E-Jurnal Mat., vol. 3, no. 1, pp. 8-16, doi: 10.24843/mtk.2014.v03.i01.p060.

Y. Tampil, H. Komaliq, and Y. Langi. (2017). "Analisis Regresi Logistik untuk Menentukan Faktor-Faktor yang Mempengaruhi Indeks Prestasi Kumulatif (IPK) Mahasiswa FMIPA Universitas Sam Ratulangi Manado". d'CARTESIAN, vol. 6, no. 2, p. 56, doi: 10.35799/dc.6.2.2017.17023.

E. Yulian and G. Pawitan. (2017). "Pemodelan Status Usaha (Pengusaha dan Pekerja/Karyawan) Menggunakan Regresi Logistik Multilevel”. J. Mat. “MANTIK,” vol. 3, no. 1, pp. 32-40, doi: 10.15642/mantik.2017.3.1.32-40. 
U. Fauzy. (2014). “Aplikasi Analisis Konjoin dengan Model Regresi Logistik dalam Mengukur Prefrensi Mahasiswa dalam Memilih Handphone". J. Mat. UNAND, vol. 3, no. 1, pp. 132-139, 2014.

S. Imaslihkah, M. Ratna, and V. Ratnasari. (2013). "Analisis Regresi Logistik Ordinal Terhadap Faktor-faktor yang Mempengaruhi Predikat Kelulusan Mahasiswa S1 di ITS Surabaya”. J. Sains dan Seni Pomits, vol. 2, no. 2.

B. R. A. Febrilia, S. Rahayu, and B. D. Korida. (2019). "Ordinal Logistic Regression Analysis of Factors Affecting the Length of Student Study”. J. Mat. “MANTIK,” vol. 5, no. 1, pp. 28-34, doi: 10.15642/mantik.2019.5.1.28-34. 